Arkadiusz TRĄBKA ${ }^{1}$

DOI: https://doi.org/10.53052/9788366249875.04

\title{
INFLUENCE OF CHANGES OF MUTUAL POSITION OF CRANE TELESCOPIC BOOM SECTIONS ON THEIR STRESS STATE
}

Summary: Telescopic booms of mobile cranes belong to the most strained parts of their structure. They are subjected to essential deformations under loads. It causes arising of stresses - especially in the zones of stress concentration - what in turn can lead to overstep strength limit of the applied material. In the paper, an assessment of an influence of changes of mutual position of crane telescopic boom sections (caused by telescopic movements) on its stress state has been performed. The analyses were performed by means of finite element method utilizing a three-section boom box-type model of rectangle form cross-section.

Keywords: telescopic boom, stress state, strength of materials, finite element method

\section{WPLYW ZMIAN WZAJEMNEGO POŁOŻENIA CZLONÓW WYSIĘGNIKA TELESKOPOWEGO ŻURAWIA NA ICH WYTĘŻENIE}

Streszczenie: W pracy dokonano oceny wpływu jaki na wytężenie członów nośnych wysięgnika teleskopowego żurawia wywiera zmiana ich wzajemnego położenia, spowodowana ruchem teleskopowania. Analizy przeprowadzono za pomocą oprogramowania metody elementów skończonych na modelu trójczłonowego wysięgnika o skrzynkowej konstrukcji i klasycznym, tzn. prostokątnym przekroju poprzecznym.

Słowa kluczowe: wysięgnik teleskopowy, stan naprężenia, wytrzymałość materiałów, metoda elementów skończonych

\section{Introduction}

The telescopic booms of mobile cranes consist of a base section and from one to a few movable sections. The essential differences in course of construction of sections result from differences of their cross-section shape. Most often the boom sections have a form of classical rectangle boxes welded of four sheet metal bands, adding some

${ }^{1}$ dr. inż., Akademia Techniczno-Humanistyczna w Bielsku-Białej, Wydział Budowy Maszyn i Informatyki, atrabka@ath.bielsko.pl 
reinforcements in the places of passing the loads [1]. Independently on the applied reinforcements, in every case if boom sections are subjected to loads, some essential deformations occur [2]. It causes that there are intensive stresses especially in zones which potentially induce stress concentration, what in turn can cause an overstepping of the ultimate strength of an applied material $[3,4,5,6,7,8]$.

In the paper, an assessment of an influence of changes of mutual position of crane telescopic boom sections (connected with elongation) on their stress state was performed. The analyses were performed for the maximally loaded boom.

\section{Model of telescopic boom}

A model of telescopic boom was performed in two steps. Firstly the geometrical model was accomplished based on the technical specification of the telescopic boom of the mobile crane HYDROS T-161 (Fig. 1) [9]. It has been done by means of commercial software Inventor. Within this phase of modeling the following assumptions were made:

- Weld junctions were omitted;

- Some holes were not taken into considerations, furthermore slightly the geometrical shape was simplified in case of slides, bolts and fixing sleeves;

- Some elements of accessories placed on the boom were omitted (e.g. hoist, locking unit against overloading, rope trolleys, etc.).

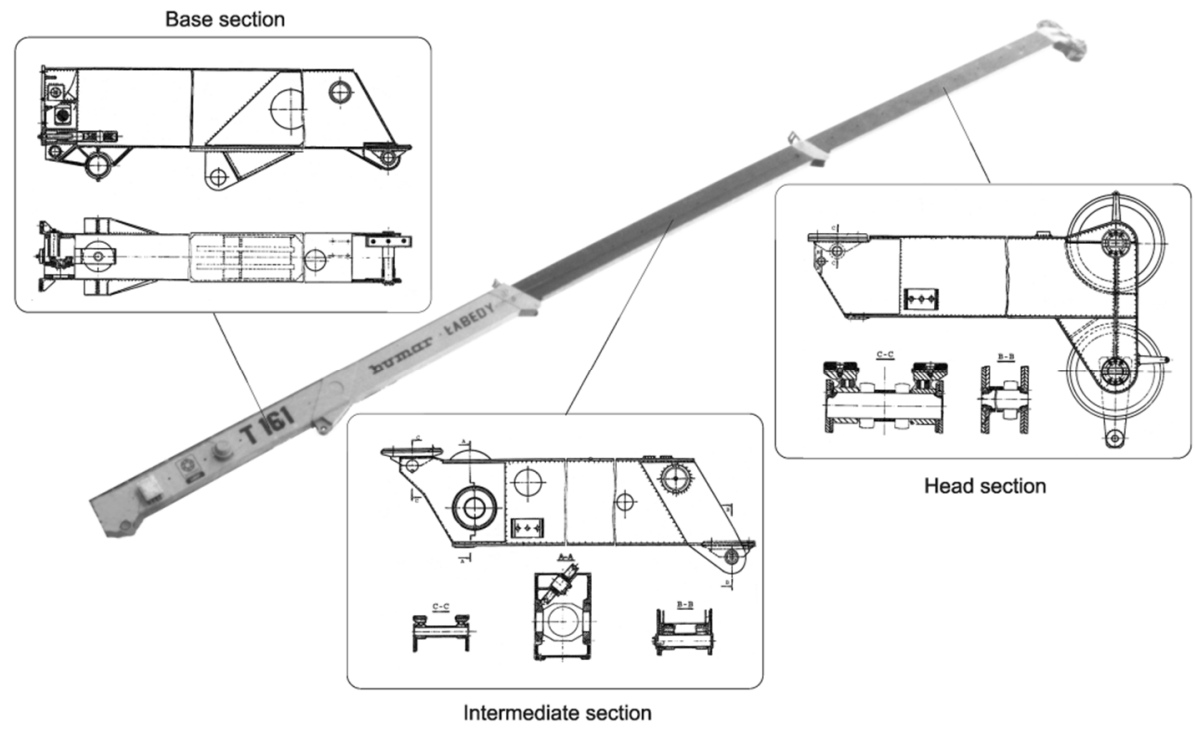

Figure 1. Telescopic boom of mobile crane HYDROS T-161 type

The obtained model is presented in Fig. 2. It consists of a main part enclosing three boom sections ( 1 - base, 2 - intermediate, 3 - head) and slides (lower, upper and side), bolts and fixing sleeves. The second part of the model consists of boom supporting elements i.e.: support and luffing hydraulic cylinder. 


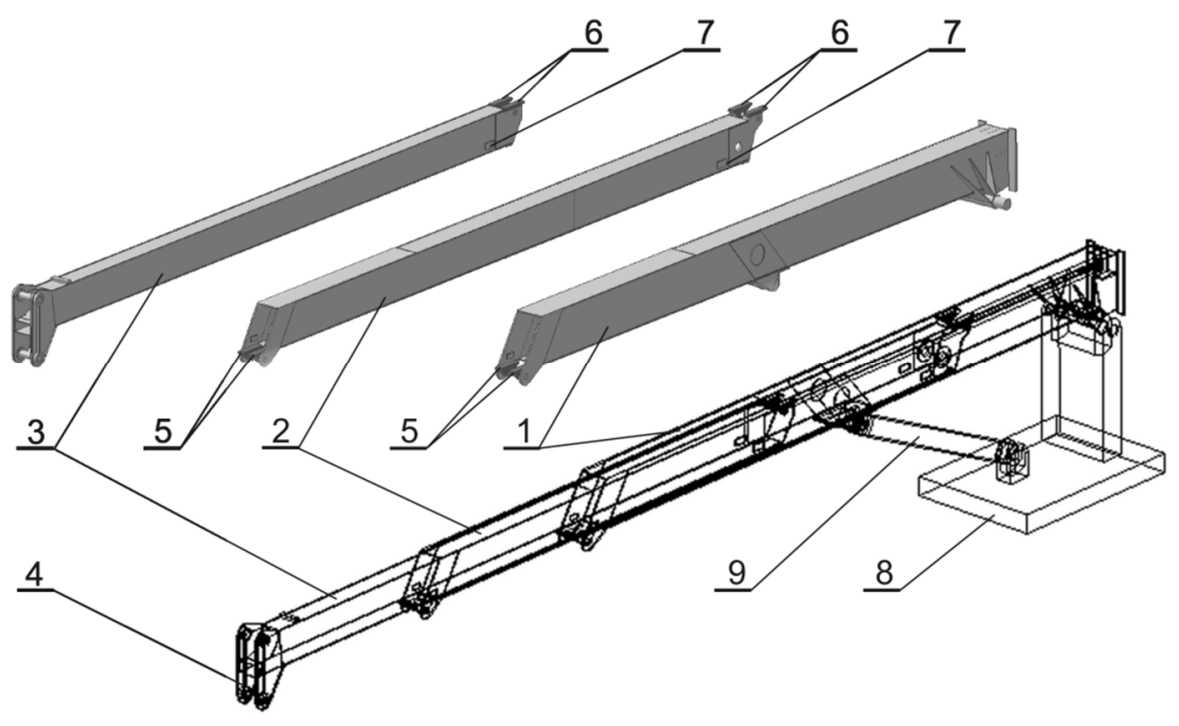

Figure 2. Model of mobile crane telescopic boom

1-base section, 2-intermediate section, 3-head section, 4-head, 5-lower slides, 6-upper slides, 7-side slides, 8-support, 9-luffing cylinder

In the second step of modeling, the boom calculation model was prepared. It was performed by means of finite element method (FEM) software FEMAP. During this phase of modeling the structure was divided into finite elements. The contact areas were defined. Additionally, material properties were determined and assigned to the particular elements of the model [10].

\section{Assumptions for calculations}

The calculations were performed for two boom inclination angles (in relation to the ground level) i.e. $\mathrm{A} 0=0^{0}$ and $\mathrm{A} 49=49^{0}$ what corresponds to possibilities of achieving the greatest reach and the greatest load capacity, respectively.

In both cases the mutual position of the boom sections were changed. The variants of work duties with a boom length equal to 8, 12, 16 and 20 meters were considered. The loads were established based upon the load charts of the mobile crane HYDROS T-161 [9]. The weight of the hook block $(2,5 \mathrm{kN})$ was also taken into consideration in total loading of the boom (Table 1).

In calculations an influence of gravity forces was taken into account. However an influence of side forces appearing during a slewing motion as well as a wind activity were not taken into considerations. 
Table 1. Total loads acting on boom head

\begin{tabular}{|c|c|c|c|c|}
\hline \multirow{2}{*}{$\begin{array}{c}\text { Boom } \\
\text { length } \\
{[\mathrm{m}]}\end{array}$} & \multicolumn{2}{|c|}{ Boom inclination angle $0^{0}$} & \multicolumn{2}{c|}{ Boom inclination angle $49^{0}$} \\
\cline { 2 - 5 } & $\begin{array}{c}\text { Reach } \\
{[\mathrm{m}]}\end{array}$ & $\begin{array}{c}\text { Load } \\
{[\mathrm{kN}]}\end{array}$ & $\begin{array}{c}\text { Reach } \\
{[\mathrm{m}]}\end{array}$ & $\begin{array}{c}\text { Load } \\
{[\mathrm{kN}]}\end{array}$ \\
\hline 8 & 5,7 & $\mathbf{6 5 , 9 7}$ & 3 & $\mathbf{1 5 9 , 4}$ \\
\hline 12 & 9,7 & $\mathbf{2 7 , 6 1}$ & 5,63 & $\mathbf{6 5 , 2 6}$ \\
\hline 16 & 13,7 & $\mathbf{1 2 , 5 1}$ & 8,25 & $\mathbf{3 2 , 4 1}$ \\
\hline 20 & 17,7 & $\mathbf{7 , 4 1}$ & 10,86 & $\mathbf{1 6 , 7 2}$ \\
\hline
\end{tabular}

\section{Results of numerical simulations}

An assessment of stress state of the telescopic boom sections was performed based on the distributions of the effective stresses calculated according to the Huber-MissesHenky's hypothesis, which assumes that the body is perfectly elastic and that the work of the equivalent stress is equal to the sum of the works of all component stresses (1).

$$
\sigma_{e q v}=\sqrt{\frac{\left(\sigma_{x}-\sigma_{y}\right)^{2}+\left(\sigma_{y}-\sigma_{z}\right)^{2}+\left(\sigma_{z}-\sigma_{x}\right)^{2}}{2}+3\left(\tau_{x y}^{2}+\tau_{y z}^{2}+\tau_{z x}^{2}\right)}
$$

where: $\sigma_{e q v}$ - equivalent stress, $\sigma_{x}, \sigma_{y}, \sigma_{z}, \tau_{x y}, \tau_{y z}, \tau_{z x}$ - component stresses.

The value of the equivalent stress determined on the basis of equation (1) was used to evaluate the strength by comparing it with the strength properties of the material. The allowable stress level, determined in accordance with equation (2), was adopted as the basis for the strength calculations [11].

$$
\sigma_{\text {allow }}=\frac{\sigma_{\text {dam }}}{n}
$$

where: $\sigma_{\text {allow }}$ - allowable stress, $\sigma_{\text {dam }}$ - damaging stress, $n$ - safety factor.

The results in a form of stress maps corresponding to considered boom lengths, for inclination angle in correspondence to the ground level equal to $49^{\circ}$, are presented in Fig. 3.

The stress maps for inclination angle equal to $0^{0}$ are placed in Fig. 4.

A comparison of distribution of the equivalent stresses along the upper, longitudinal edge of each boom section (Fig. 5) is shown in Figures 6-8.

In consecutive figures a comparison of the maximal equivalent stresses in particular sections of the boom depending on the boom length is presented. In Fig. 9 the maximal equivalent stresses in boom sections for inclination angle in correspondence to the ground level equal to $49^{\circ}$, are compared. Similarly in Fig. 10 the maximal equivalent stresses for inclination angle $0^{\circ}$, are compared.

Finally, in Fig. 11, resultant displacements of the boom head are presented. 

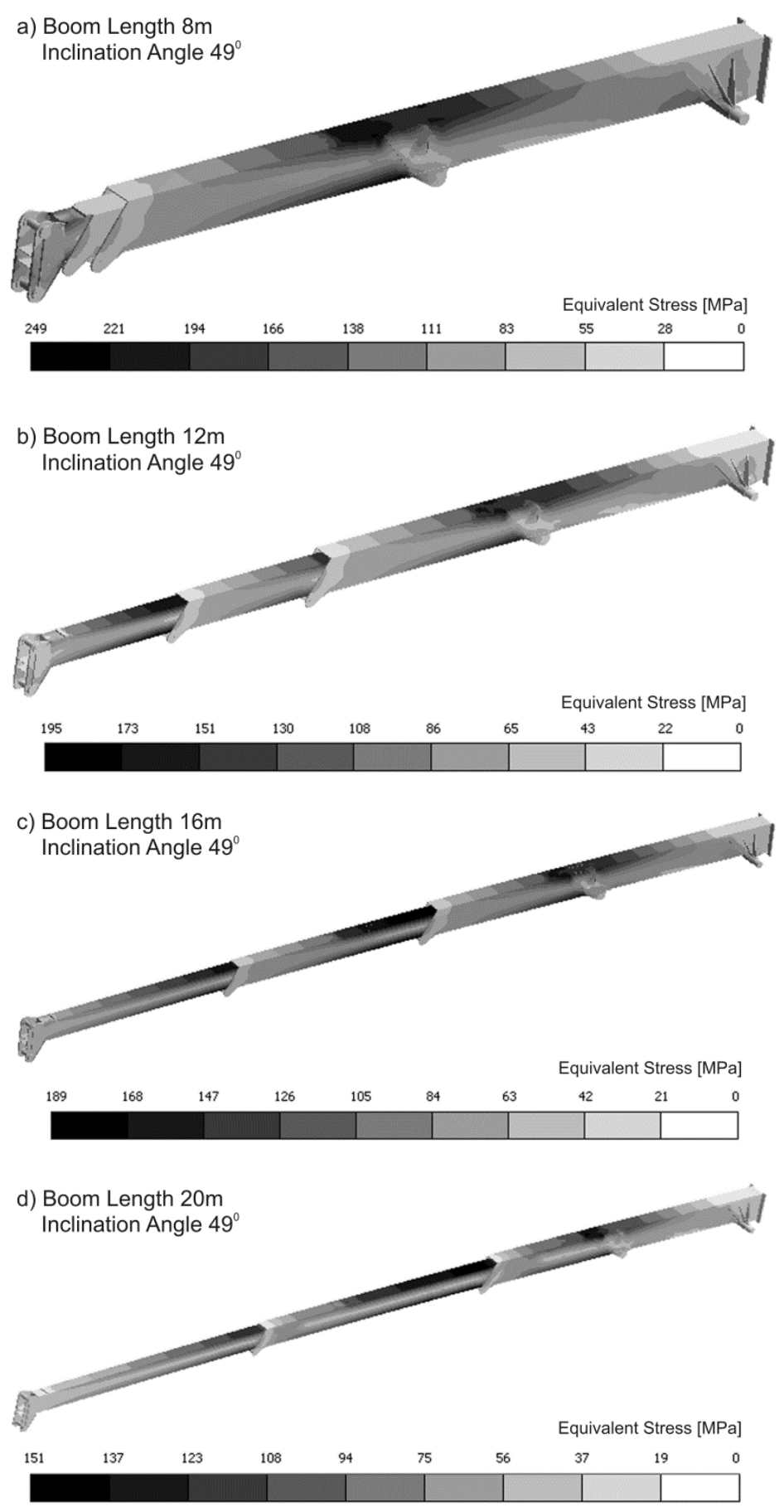

Figure 3. Equivalent stresses for boom length of a) $8 \mathrm{~m}, b) 12 \mathrm{~m}, \mathrm{c}) 16 \mathrm{~m}$, d) $20 \mathrm{~m}$, and for inclination angle in correspondence to the ground level equal to $49^{\circ}$ 

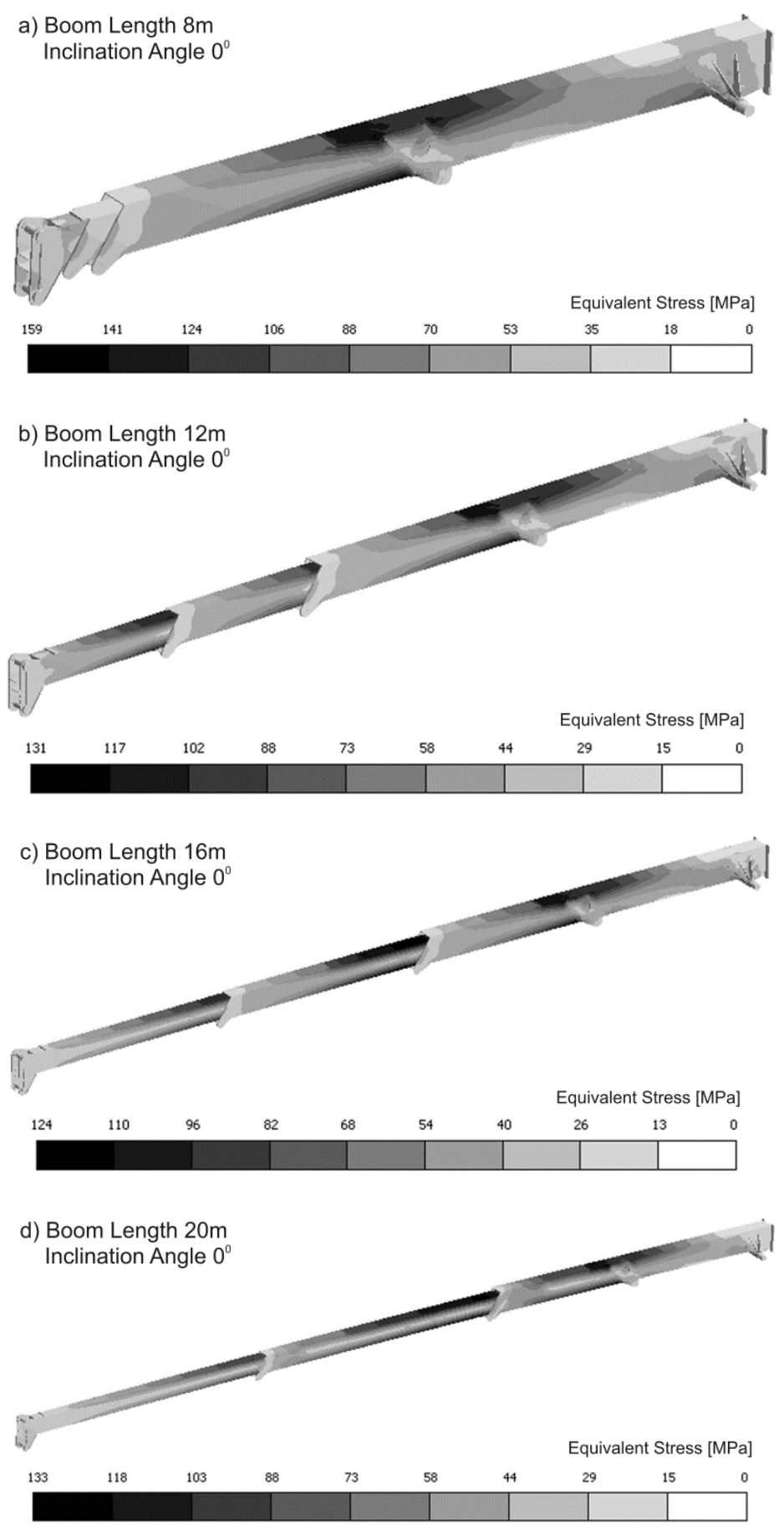

Figure 4. Equivalent stresses for boom length of a) $8 m$, b) $12 \mathrm{~m}, \mathrm{c}$ ) $16 \mathrm{~m}$, d) $20 \mathrm{~m}$, and for inclination angle in correspondence to the ground level equal to $0^{\circ}$ 


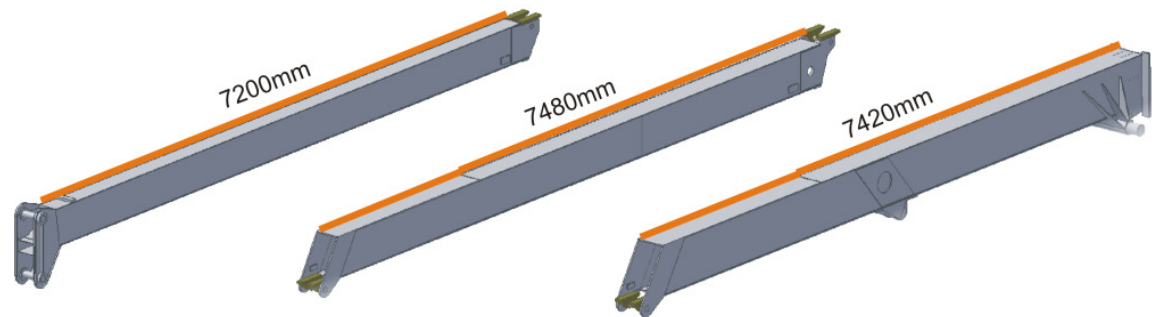

Figure 5. Position of edges along which the equivalent stresses shown in Figures 6-8 have been read

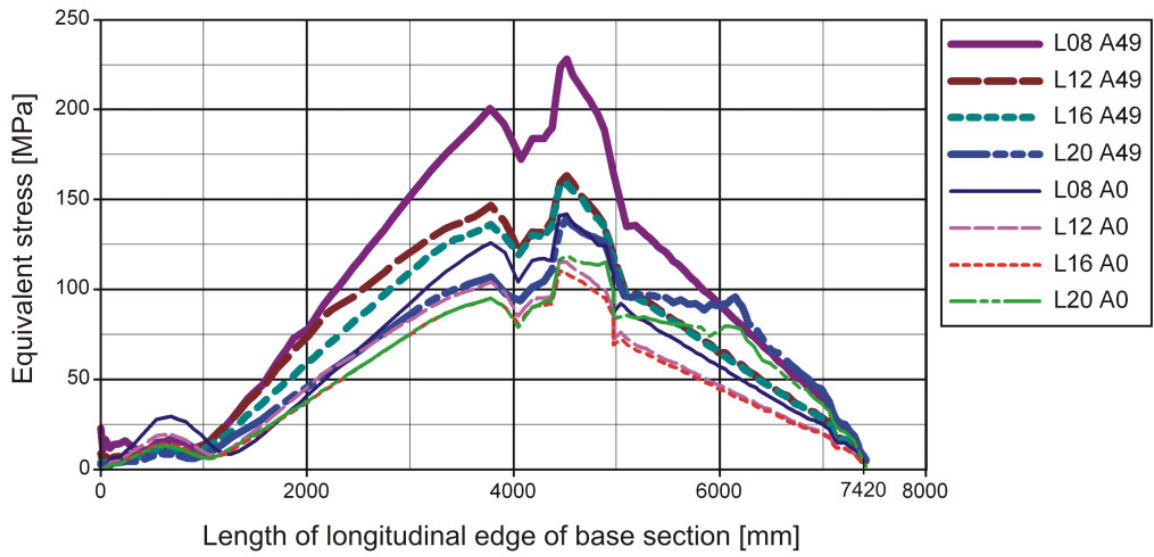

Figure 6. Distribution of equivalent stresses along the upper, longitudinal edge of the base section for angles of inclination: $0^{\circ}, 49^{\circ}$ and for different boom lengths

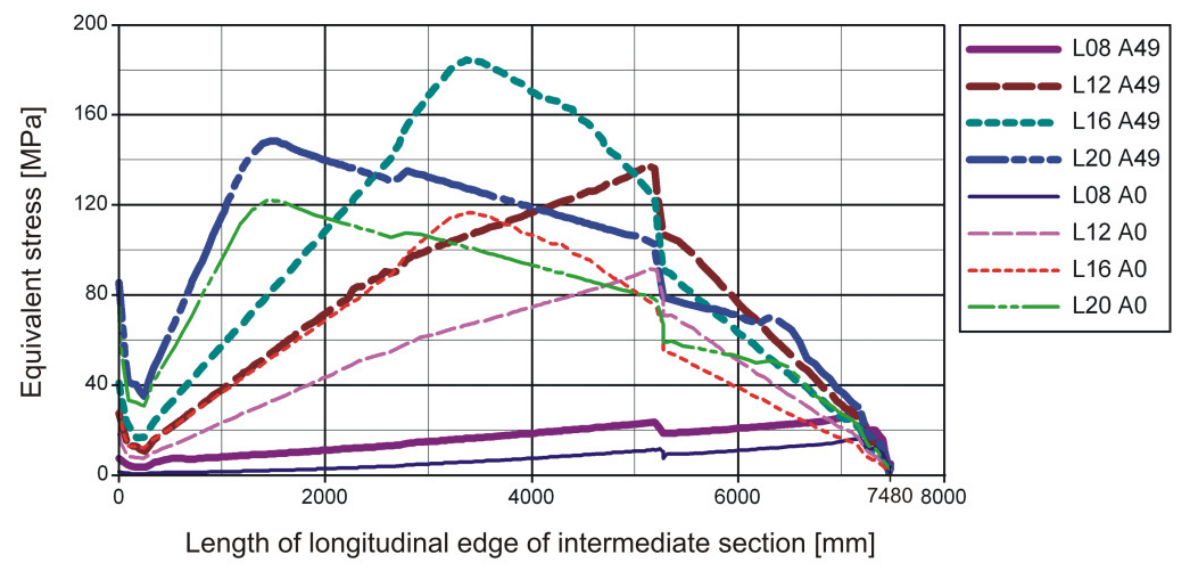

Figure 7. Distribution of equivalent stresses along the upper, longitudinal edge of the intermediate section for angles of inclination: $0^{\circ}, 49^{\circ}$ and for different boom lengths 


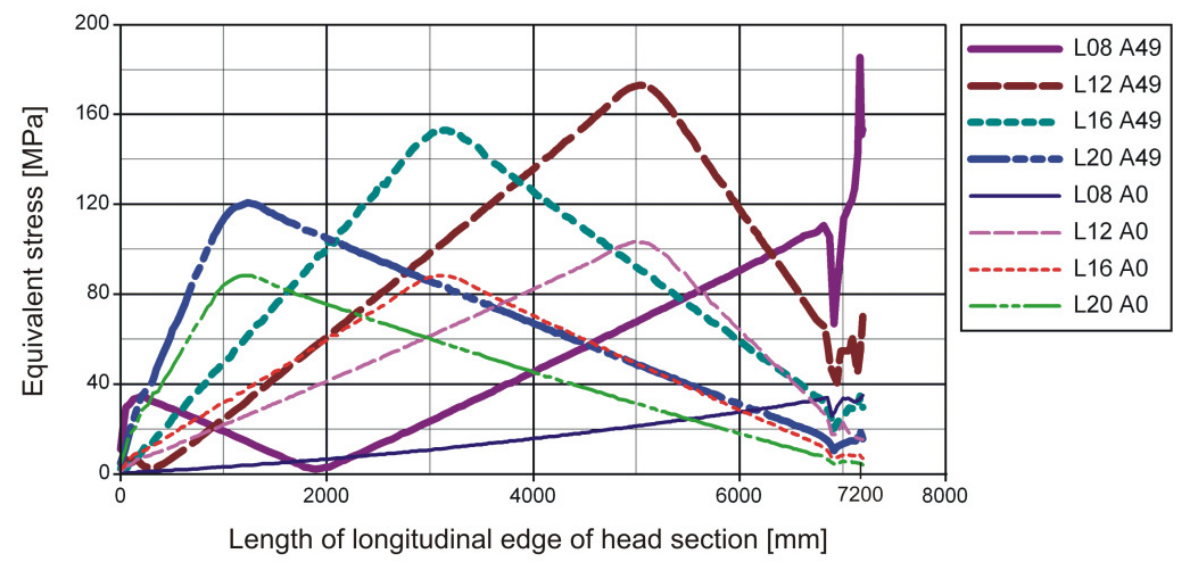

Figure 8. Distribution of equivalent stresses along the upper, longitudinal edge of the head section for angles of inclination: $0^{\circ}, 49^{\circ}$ and for different boom lengths

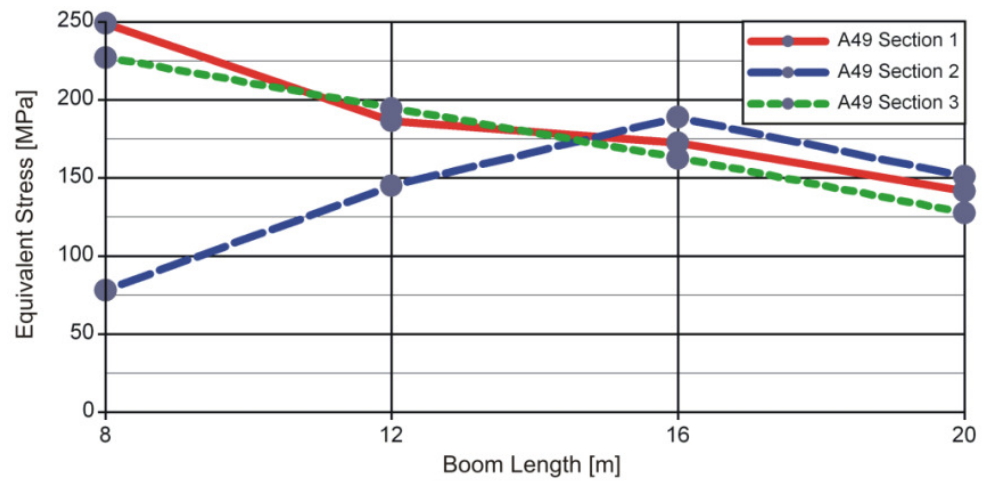

Figure 9. Maximal equivalent stresses in particular sections (section 1 - base, section 2 -intermediate, section 3 - head) depending on boom length for inclination angle in correspondence to the ground level equal to $49^{\circ}$

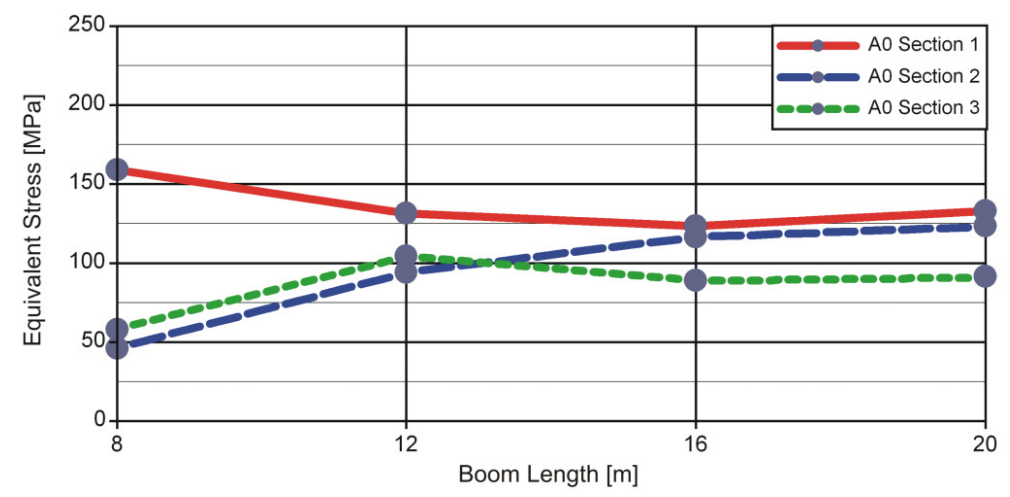

Figure 10. Maximal equivalent stresses in particular sections (section 1 - base, section 2 -intermediate, section 3 - head) depending on boom length for inclination angle in correspondence to the ground level equal to $0^{\circ}$ 


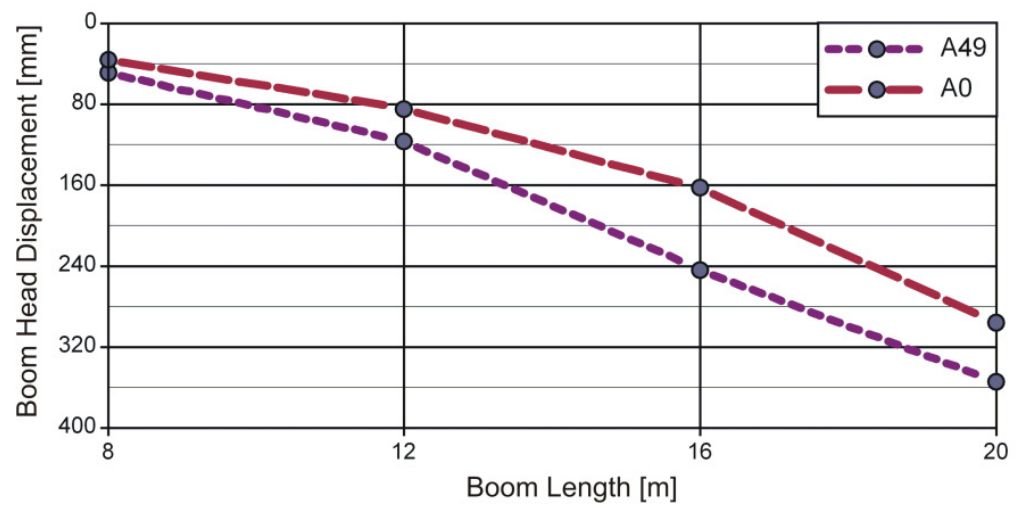

Figure 11. Resultant displacements of the boom head depending on boom length and inclination angle in correspondence to the ground level $\left(A O=0^{\circ}, A 49=49^{\circ}\right)$

\section{Conclusions}

Based upon the results of numerical simulations it can be stated that:

- The highest stresses appear in the base section in the neighbourhood of mounting area of the luffing cylinder;

- In intermediate and head sections localization of the areas of the highest stress is essentially connected with the positions of the slides, which were responsible for passing of loading;

- The highest equivalent stress (249MPa) is slightly greater then the allowable stress for 18G2A steel (of which the analysed structure was made $\left.\left(\sigma_{\text {allow }}=245 \mathrm{MPa}\right)\right)$. However it is still essentially lower then the yield stress $\left(R_{e}=355 \mathrm{MPa}\right)$, what assures a safe usage of the boom;

- In case of placing the boom in a position of the maximal reach (inclination angle in relation to the ground level equal to $0^{0}$ ) within whole its range the base section is the maximal strained element;

- In case of placing the boom in a position corresponding to the maximal load capacity (inclination angle in relation to the ground level equal to $49^{\circ}$ ), during elongation the maximal stresses appear consecutively in the sections: base, head and intermediate, respectively;

- Within the boom length from 8 to 12 meters, the stress distribution along particular boom sections is highly uneven;

- Within the boom length from 16 to 20 meters, the ratios among the maximal stresses in particular boom sections remain at a similar level;

- In case when the boom inclination angle (in correspondence to ground level) is equal to $49^{\circ}$, the maximal stresses in the head section within whole length range are very similar to these ones which occur in the base section. 


\section{REFERENCES}

1. SOSNA E.: Evolution of structure of constructional forms of mobile cranes / Ewolucja strukturalna ustroju nośnego żurawi samochodowych. II Ogólnopolska Konferencja Mechaniki Maszyn Włókienniczych i Dźwigowych, Mechanika 73, Zeszyty Naukowe Politechniki Łódzkiej, 1985, 323-339.

2. SOSNA E.: Influence of flexibility of support system on dynamics of the telescopic mobile crane / Wpływ podatności układu podporowego na dynamikę żurawia teleskopowego. Praca doktorska, Politechnika Łódzka, 1984.

3. KUKLA S., POSIADAŁA B., PRZYBYLSKI J., TOMSKI L.: Analysis of an influence of geometric parameters on the distribution of stresses in a telescopic boom / Analiza wpływu parametrów geometrycznych na rozkład naprężeń w wysięgniku teleskopowym. Materiały Konferencyjne II Międzynarodowej Konferencji Naukowo-Technicznej „Rozwój i Kierunki Badań Samojezdnych Żurawi Hydraulicznych", Radziejowice, 21-23 listopada 1994, Część I, Zeszyt 23, 75-82.

4. PAVLOVIC A., FRAGASSA C., MINAK G.: Buckling analysis of telescopic boom: theoretical and numerical verification of sliding pads. Tehnički Vjesnik, 24, 3(2017), 729-735.

5. RUSIŃSKI E.: Microcomputer analysis of frames and bodies of vehicles and working machines / Mikrokomputerowa analiza ram i nadwozi pojazdów i maszyn roboczych. Wydawnictwa Komunikacji i Łączności, Warszawa 1990.

6. HAN D.S., YOO S.W., YOON H.S., KIM M.H., KIM S.H., LEE J.M.: Coupling analysis of finite element and finite volume method for the design and construction of FPSO crane. Automation in Construction, 20 (2011), 368-379.

7. DERLUKIEWICZ D., PRZYBYŁEK G.: Chosen aspects of FEM strength analysis of telescopic jib mounted on mobile platform. Automation in Construction, 17 (2008), 278-283.

8. RUST W., SCHWEIZERHOF K.: Finite element limit load analysis of thinwalled structures by ANSYS (implicit), LS-DYNA (explicit) and in combination. Thin-Walled Structures, 41 (2003), 227-244.

9. Technical specification and table of load capacities of hydraulic, telescopic mobile crane HYDROS T-161 build on undercarriage STEYR type 034 / Dane techniczne oraz tabela udźwigów żurawia samochodowego, hydraulicznego, teleskopowego, HYDROS T-161 na podwoziu STEYR typ 034.

10. TRĄBKA A.: Dynamics of telescopic cranes with flexible structural components. International Journal of Mechanical Sciences, 88 (2014), 162-174.

11. BĄK R, BURCZYŃSKI T.: Strength of materials with elements of a computer approach / Wytrzymałość materiałów z elementami ujęcia komputerowego. Wydawnictwa Naukowo-Techniczne, Warszawa 2013. 